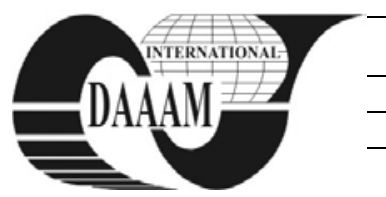

Annals of DAAAM for 2011 \& Proceedings of the 22nd International DAAAM Symposium, Volume 22, No. 1, ISSN 1726-9679 ISBN 978-3-901509-83-4, Editor B. Katalinic, Published by DAAAM International, Vienna, Austria, EU, 2011 Make Harmony between Technology and Nature, and Your Mind will Fly Free as a Bird Annals \& Proceedings of DAAAM International 2011

\title{
THE PROCESS OF FORMING HUMAN CAPITAL OWING TO EDUCATION
}

\author{
MACRIS, M[aria]; MAN, M[ariana]; BOCA RAKOS, I[leana] S[orina] \& GADAU, L[iana]
}

\begin{abstract}
The paper approaches an extremely interesting matter regarding the evolution of the process of forming human capital owing to the educational system. In order to carry out this study we have started from a thorough documentation concerning the leading part played by human capital in society, in general, and at an educational level, in particular. The analysis of the approached issue has emphasized certain aspects regarding the evolution of the complex process of forming human capital owing to education.
\end{abstract}

Key words: capital, formation, education, investment

\section{INTRODUCTION}

Human capital and education in present-day economy rely upon settling the knowledge stage of the research field. Today's economies consider the investments in education and in employees' formation at least as important as patrimony investments. We live in an information-based economy where technology and production methods rapidly and constantly change. The formation of human capital should be approached at least according to the manner physical capital is analyzed while educational reform should be directed towards the notion the economists call "capital formation" - although the formation of the human capital is sometimes forgotten.

There are quite a lot of specialized works in the field so that the approach we have in view might also interest other specialists.

In the future, the approach may be developed by taking into account the new economic and social context affected by the economic world crisis that requires a special attention given to the development of human capital owing to education with a view of matching the demands of society and labour market.

\section{THE PROCESS OF FORMING HUMAN CAPITAL OWING TO EDUCATION}

The process of acquiring and using certain productive goods such as lands, buildings or equipments is frequently called "capital formation". The formation of capital is a primary means of increasing labour productivity. Basically, it represents, from the point of view of the amount, the result determined by each employee while the increase of labour productivity is synonymous with higher salaries and economic prosperity. When a person or a company acquires a "real" good, such as a new device in order to determine future incomes, they expect the investment to be efficient. Nevertheless, a minimum income determined by such an investment is required. This minimum income shows anticipated inflation and various other risks associated with the investment. Such a minimum income is often called "normal" income or "normal" profit; any other income, besides the previously mentioned one, is called "economic" profit.

No product created itself so far nor did it create another one beginning with conception up to its complete achievement. Let's consider, for instance, a car: inventive people are required in order to imagine what a new car might do, how it can be elaborated, manufactured, tested, and, finally, used. These innovators and creators have several common traits, and one of them regards a certain degree of education. Once the car has been built and is ready to be used, other people are required to do this thing. These people too need a certain degree of education; they all embody the "formation of human capital".

Education plays an essential part in forming "human capital" and in determining an individual's chance from an economic perspective. Business environments, of course, display a lot of stories connected with people who, although having attended only high schools or even less, have had huge success and made extraordinary fortunes. At the same time, in certain countries, economy witnesses a lot of persons who, although having their PhDs, earn financially small wages. Nevertheless, leaving aside such exceptions, the more persons are educated the higher the chances and economic success.

This is not only a theoretical observation; it may also have important practical consequences upon economic growth. Certain governmental policies, for instance the fiscal one, may discourage individuals in their attempt to attend higher levels of education; accordingly, the productive capacity of national labour force decreases. Education generally determines the growth of individuals' anticipated incomes during their life, being perceived as a long term effort. Nevertheless, in case individuals' taxes are higher as their incomes increase, fiscal policy discourages them to use their time and required resources in order to get a higher level of education. High taxes punish success and discourage people to act with a view of getting it, no matter whether the required actions represent more work or a higher level of education. In other words, in case taxes grow with incomes, they discourage the formation of human capital according to the same manner they discourage work, savings or investments in physical capital.

The formation of human capital can also be discouraged through other means which are less known or understood. For instance, within present-day economy, most families understand the importance of higher education. In case educational effort is going to decrease, it will mostly discourage the families having modest incomes rather than the well-offs. The families having higher incomes are able to bear to a larger extent the increased costs of higher education than the families with lower incomes.

In quite a lot of cases, governments have roughly dealt with the formation of human capital as compared with the formation of physical capital. An essential feature of individuals as producers of economic value is given by the sum of their capacities, experience, and knowledge. As individuals, we develop our human capital owing to life experience, professional training, and education; the quality and amount of our human capital determine to a large extent our capacity to contribute to the development of economy or to our own earnings (http://econlib.org/LIBRARY/CEE Category.html, 2010).

For generations, families have made sacrifices in order to help certain of their children study more; they accordingly considered that they were offering their children a better life. 
Sometimes this is only a belief in the intrinsic higher quality of the life of an educated person. Most often, parents have understood that a higher level of education determines increased opportunities of building a career, of getting higher incomes, and of gaining financial safety.

Education is important during all good and stable periods as it is more probable that an individual that might have success in several fields is ready to direct oneself towards those activities which are mostly demanded on labour market. And when economy does not function properly, such a higher level of mobility regarding one's job allows the individual to adapt in case circumstances are not favourable (Bedrule-Grigoruţă, 2006). Economists have tried to determine an anticipated efficiency of the investment in an individual's education. Accordingly, considering anticipated costs (study fees) and anticipated incomes, they have focused upon the calculation of efficiency rate which results out of the income differences of various levels of education. Specialized works have reached an important conclusion, namely that "education has a more important effect upon the macro level than upon the micro one" (Heckman \& Klenow, 1998).

Education brings society an extra-benefit which is not manifest at the individual level. The formation of human capital is very important for an individual's own capacity to contribute to the development of economy and to earn more; nevertheless, one should not ignore the social consequences of a population having a higher level of education. Education brings society numberless benefits, a lot of them having important effects upon the manner economy, companies, and institutions function. A higher level of education may be associated with stability. Stable families properly evaluate the consequences of education than disorganized families. The more a people are educated the more its communities are stable as confidence and self-consciousness encourage a higher respect for human rights.

In case of Romania, one can state several unhappy findings connected with the stage of education benefits within society's development. One of the most evident gains of democracy is the fact that it offers its citizens the right and capacity to administrate their own life and education, beginning with a certain level, without State's intervention. Yet, one of the most important dangers of democracy shows itself when individuals continually exert these rights and capacities and ignore the external events that influence their lives and the future of the nation. The relative easiness of getting higher education diplomas or even doctoral studies ones, during a certain period of economy, as has happened in Romania or in other East European countries, is not going to determine the expected effects at a macro-economic level, or at the practical level of companies' or institutions' behaviour. At its turn, democracy, with its respect for human rights - for instance, the right to education - is the most natural political system capable to support an economy based upon free market.

In case of Romania, among the elements that characterize an educational system, one can enumerate: transparency, simplicity, difficulty in administering the funds required by "education investments" as well as the improper treatment of the educational staff as compared with other social categories. On the other hand, the teaching staff and the organisms representing them when facing educational policies are concerned by the degradation of salaries and work conditions as well as by their marginalized position in adopting the decisions regarding individuals' inclusion within educational systems (Pîrvu \& Măcriş 2010). Collective negotiations concerning certain components of the educational system (salaries, work conditions, etc.) are rare and inexistent in certain countries; the argument for such attitudes is the decreased level of the public field budget for education as compared with that of the highly developed countries. The strikes and protests of the educators or of those being educated determine governments to admit the need of radical reforms of the present educational systems at the disposal of the citizens with a view of forming the future human capital.

An important preoccupation of world-wide governments consists in adapting education and individuals' formation to the needs of economy through displaying a real necessary relation between education and labour market. This correlation is also shared by the companies and institutions interested in employing as they are sensitive to the capacity of the educational system to offer their potential employees enough abilities and skills that make them ready to face the challenges of global economy and competitors.

The State contributes to the carrying out of an investment process in education owing to giving credits to students or to paying certain non-taxable scholarships. In the economic field, the funds for research and development, as percent of CDP, are quite small while investments in education are also reduced. Within a free and globalized market and although they are better developed and richer than the Romanians, the English, Irish, Finish or even Taiwanese have found out that they do not possess enough public funds so that they can provide the sums required by education with a view of carrying out its part as a main factor of economic growth. The solution they have found out is "the public-private partnership" understood according to two different aspects: the first one is that of encouraging private education while the second one is that of encouraging the system of sponsorships for education made by private natural or juridical persons.

\section{CONCLUSION}

Investments in the development of human capital owing to education and training are required in order to strengthen the system's capacity to face the rapid changes in society and labour market.

Nowadays, Romania has to rapidly carry out its goal regarding the investment in human capital; and to do this, it is necessary to go through several stages, not only conceptual, but of mentality, as follows:

$>$ Understanding the fact that, without a rapid and deep progress of the educational system, we are going to have neither economic growth nor the increase of the living standard no matter how much money the European Union or any other international institution would allocate us.

$>$ Changing the management mentality of the Ministry of Education, Research, Youth, and Sports with a view of a real re-organizing and reforming of the whole educational system.

$>$ Changing the mentality of the citizens, of the business men and women, parents and children, understanding that investments in education represent the most important future objective.

The formation of human capital owing to investment educational processes is a global responsibility of all individuals and governments.

\section{REFERENCES}

Becker, G.S. (2011). Human Capital, Available from: http://econlib.org/LIBRARY/CEECategory.html. Accessed: 27.02.2011

Bedrule-Grigoruţă, M. (2006). Capitalul uman şi investiţia în educatie, Scientific Annals of "Alexandru Ioan Cuza" University of Iasi, Economic Sciences, Vol. 52 - 53, ISSN 0379 - 7864, Iaşi

Heckman, J. \& Klenow, P. (1998). Human Capital Policy, in Policies to Promote Capital Formation, M. Boskin Editor, Hoover Institute

Pîrvu, Gh. \& Măcriş, A. (2010). Economia contemporană a României, Politica de integrare europenă în domeniul educaţiei, Vol. 9, Universitaria Publishing House, ISBN 978-606-510-797-7, Craiova 